\title{
ÉLISÉE RECLUS CONTRIBUITIONS TO THE DEBATE ABOUT THE AGRARIAN QUESTION
}

https://doi.org/10.4215/rm2020.e19026

\author{
Sergio Aparecido Nabarro ${ }^{*}$
}

(a) Phd. in Geography. University of Sao Paulo, São Paulo (SP), Brazil.

ORCID: https://orcid.org/0000-0003-2179-0710. LATTES: http://lattes.cnpq.br/8538298464713169.

\section{Article history:}

Received 20 April, 2020

Accepted 11 August, 2020

Publisher 15 November, 2020
(*) CORRESPONDING AUTHOR

Address: 191, rue Saint-Jacques - 75231 Paris. Phone (+33)01443214 00.

E-mail: sergionabarro@gmail.com

\begin{abstract}
The purpose of this article, is to analyze the contribution made by the French anarchist-geographer (Élisée Reclus) on specific issues related to the agrarian question. For this, from the vast work of the libertarian intellectual, the political and geographic texts were selected, which he approached with greater private appropriation of the land and the peasant question based on the atrocious assumptions. Among the results, the importance of unity and the centrality of the struggle of workers (rural and urban) against the State and capital and the potential of peasants as agents and protagonists of this process stand out.
\end{abstract}

Keywords: Élisée Reclus; Anarchist Thought; Private Property; Agrarian Question; Peasantry.

\section{Resumo / Résumé}

\section{CONTRIBUIÇÕES DE ÉLISÉE RECLUS AO DEBATE SOBRE A QUESTÃo AGRÁRIA}

O objetivo deste artigo é analisar o aporte elaborado pelo anarquista-geógrafo francês (Élisée Reclus) sobre assuntos específicos ligados à questão agrária. Para isso, a partir da vasta obra do intelectual libertário, foram selecionados os textos políticos e geográficos aos quais ele abordou com maior a apropriação privada da terra e a questão camponesa a partir dos pressupostos ácratas. Entre os resultados destaca-se a importância da união e a centralidade da luta dos trabalhadores (rurais e urbanos) contra Estado e capital e o potencial dos camponeses como agentes e protagonistas deste processo.

Palavras-chave: Élisée Reclus; Pensamento Ácrata; Propriedade Privada; Questão Agrária; Campesinato.

\section{CONTRIBUITIONS D’ÉLISÉE RECLUS AU DÉBAT SUR LA QUESTION AGRAIRE}

L'objectif de cet article est d'analyser la contribution de l'anarchiste-géographe français (Élisée Reclus) sur des questions spécifiques liées à la question agraire. Pour cela, à partir du vaste travail de l'intellectuel libertaire, les textes politiques et géographiques ont été sélectionnés, qu'il a abordés avec une plus grande appropriation privée de la terre et la question paysanne du point de vue anarchiste. Parmi les résultats, l'importance de l'unité et la centralité de la lutte des travailleurs (ruraux et urbains) contre l'État et le capital et le potentiel des paysans en tant qu'agents et protagonistes de ce processus sont mis en évidence.

Mots-clés: Élisée Reclus; Pensée Anarchiste; Propriété Privée; Question Agraire; Paysannerie. 


\section{INTRODUCTION}

French anarchist Jacques Élisée Reclus (1830 - 1905) is considered one of the most important geographers of the nineteenth century and produced a vast corpus on topics related to geographic science, sociology, and the foundations of anarchist thought. However, although he was a contemporary of great academic geographers such as Alexander von Humboldt (1769 - 1859), Carl Ritter (1779 1859), Friedrich Ratzel (1844 - 1904), and Paul Vidal de La Blache (1845 - 1918), his thinking developed outside the universities and research institutes, in the political debate and the militancy against the institutions of the Establishment (Church, and Capital). Furthermore, his two long periods in exile, as well as his travels to collect data for his magnum opus, took him through the American, European, Asian, and African continents, bringing him into contact with new realities and giving him an understanding that transcended the French context. As a result, the knowledge he produced lacked the underlying academic concerns of the time, namely, respect for the limits between the areas of knowledge and their particular objects of research. Therefore, his vision of geography was shaped by the analysis of phenomena in different regions of the Earth, encompassing their dynamics and totality and thus negating the academic dichotomies of European geographic thought at the end of the nineteenth century, such as Physical Geography vs Human Geography, and environment vs society.

His analytic method also differed markedly from his contemporaries. Based on anarchistic suppositions, such as the defense of freedom, promotion of the citizens' consciousness and collectivism, and combating the forms of power, hierarchy, and property, Reclus analyzed phenomena from a dialectic movement based on the evolution-revolution succession. They happen in a kind of civilizing spiral composed of consecutive periods of change in social relations (evolution), which promote questioning of the status quo, and periods of rupture with the pillars of the current social organization (revolution), which lead to the foundation new social bases. The analysis ensuing from this relationship occurs through three variables, which he calls laws, which make up an analytical triad: the "class struggle", the "search for balance" and the "sovereign decision of the individual" (RECLUS, 1905, p. III-IV).

Reclus' theoretical-methodological analysis sought to understand the political, social, and territorial implications of capitalist expansion in the second half of the nineteenth century, and, given this scenario, the agrarian issue was one of the most relevant themes. The decline in communal peasant areas, the precariousness of labor relations in the countryside due to the expansion of private land ownership, and the concentration of land ownership were fundamental elements that aroused his interest in grasping the problem. He perceived the agrarian issue as an essential element supporting capitalist logic, therefore, something that revolutionaries should combat to establish a more just society.

Our studies and work by Zaar (2015), indicates some recurrent themes related to the agrarian issue in Reclus's work, such as the crisis of the communal land regime, the social importance of peasant property, land appropriation and use in the former European colonies, and the role of peasants in the revolution. From these themes, our research methodology analyzes the most relevant works on these subjects. It is important to note that, although the author's production is vast, we have prioritized texts with a greater political and methodological bias. Thus, of his three great geographical works, La Terre (The Earth), Nouvelle Géographie Universelle (New Universal Geography), and L'Homme et la Terre (The Earth and its Inhabitants), only the latter was analyzed in greater depth. Despite their importance and density, at the time the first two were written the author's intention was not to explicitly politicize their contents (FERRETTI, 2014 and 2018). Also, before publication, they were subjected to "critical reading" that made changes and/or suppressed content. L'Homme et la Terre, the most significant work from a methodological point of view, analyzes, among other themes, the importance of private property as the foundation of the capitalist mode of production. Therefore, it is essential in the study of the agrarian question. Other texts, letters, and pamphlets/manifestos written by the author were included in the analysis.

To facilitate the readers' comprehension, the analyzes developed in this article have been divided into three parts. The first provides the context by addressing the centrality of the agrarian issue in the social and economic debate of the nineteenth century, which was almost entirely centered on the clash between liberals and socialists. The second part examines Reclus' anarchist observations on private land ownership, understood by him as fundamental to the concentration of wealth and power, and historically 
legitimized by the State and Church. Finally, the third section is dedicated exclusively to understanding the peasant issue from Reclus' perspective.

\section{LIBERALS AND SOCIALISTS: THE DEBATE ON THE AGRARIAN ISSUE IN THE NINETEENTH CENTURY}

The consolidation of industrial capitalism and the profound economic, political, and social transformations it provoked in the eighteenth and nineteenth centuries were the subjects of countless discussions, studies, and reflections, the highlight of which centered around the debate between liberals and socialists.

Since the Glorious Revolution of 1688 in England, originated by the clash between the Catholic King James II and the Protestant bourgeoisie, liberal thought has also assumed a political-economic dimension. This principle is based on premises such as the defense of the freedom of individuals and their equality before the law, free commercial initiative, the limitation of State power, and the defense of private property (ECCLESAHLL, 2011). Therefore, liberal doctrine is anchored in the philosophical current of individualism and sought to consolidate a new model of social organization that definitively broke with feudal vestiges, which were rooted in the monarch's totalitarian power, and made no distinction between state and religion.

When organizing society based on these premises, liberal thought fit perfectly with the new economic reality imposed by the development of European industrial capitalism, although, in fact, social inequality widened. However, for liberals, business success and the expansion of private property would generate jobs and tax revenue, benefiting the whole of society (MARQUES NETO, 2009). From this proposition, inequality between people is understood as natural in society. Economic and social differences between individuals are related to personal failure or success, that is, liberals defend the ideology of prosperity through work. It was up to workers to collaborate with the bosses in order, who knows, to become one of them one day.

Based on liberal assumptions, a new interpretation of citizenship emerged, in which individuals are an end in themselves rather than subjects whose lives are decided by unstable rulers acting in their own interests. Above all, this debate sustained an uncompromising defense of the inalienable right to private property, consolidating the foundational premises of liberalism as a model of social organization (NABARRO, 2014). Consequently, the preservation of goods became the cornerstone that guaranteed individual freedom, as well as economic stability and the development of society.

However, the concentration of wealth and widening inequality supported other interpretations of the socio-economic dynamics of capitalism and its consequences, among which socialism was the most prominent.

Based on the premise of the Enlightenment philosopher Jean-Jacques Rousseau (1712 - 1778) that society should be a harmonious community composed of individuals on equal terms (ROUSSEAU, 1962), socialism contends that inequalities are not natural and cannot be naturalized because they are products of unjust social relationships. Thus, it is unacceptable to consider poverty a result of personal failure or indolence. It results from the unequal development among individuals that takes place in the capitalist mode of production through the concentration of the private property of land and the means of production, as well as the exploitation and precariousness of labor relations its dynamics imposes.

The most well-known contribution to the theme of private property was that of Karl Marx, who was influenced by the writings of Proudhon (1841) and Hegel (2003). Although these two thinkers disagreed profoundly in their understanding of the State, they were both extremely critical of the prevailing social organization in the first half of the nineteenth century. Proudhon defended the end of the State and private property, which he considered theft. For Hegel, the development of the State would be more just and adequate if it were based on family-owned agrarian properties.

Marx considered that the liberal political-legal organization made private property the essence of an exclusionary society, in which traditional customs, especially of the rural population, were summarily disregarded by legislators (MARX, 1975). Also, he points to the total inconsistency of legal provisions regarding the "thefts" of wood, in theory practiced by peasants on the estates of large landowners linked 
to urban industry. Marx points out that, by failing to differentiate between the extraction of wood (felling of trees) and the gathering of wood from the ground (a traditional peasant practice), the law considers any action as theft. In this way, the legislator, in reality, creates a legal apparatus that protects private property and condemns traditional peasant practices, especially collective ones. (MARX, 1975; VIEIRA, 2019)

The reality imposed by the liberal social, political and legal organization resulted in the expulsion of large contingents of peasants, who joined the proletariats in the cities, during the brutal concentration of private land ownership in Europe in the eighteenth and nineteenth centuries (HOBSBWAM, 1983 ). Several socialist studies were carried out to understand the genesis and impacts of these profound transformations. However, although they considered the agrarian issue as a part of the origin of urban problems, most of these studies, including Marx's, were focused in-depth on the urban-industrial question, including the concentration of the means of production and the increased precariousness of industrial work.

However, the events that unfolded as a result of the severe economic crisis of the $1870 \mathrm{~s}$, which started in 1873 with the dissolution of the Vienna Stock Exchange, caused serious upheaval in agricultural activity, and later in industry, prompting socialists to place the analysis of the agrarian issue at the center of their thinking.

As the impacts of the crisis reached practically all of Europe between the decades of 1880 and 1890 , it was up to Marx's intellectual followers to study the agrarian issue and present a socialist alternative to the catastrophe.

A series of meetings were organized to consider the socialist proposal, in Marseille (1892), Nantes (1894), Zurich (1893), Brussels (1893), Frankfurt (1894), and Bratislava (1895). At these gatherings, socialists recognized that agricultural space was just as important for the expanded reproduction of capital as industrial activity. They decided to draw up a proposal centered on understanding the situation of peasants in the face of the development of capitalism in the countryside. However, after the Bratislava meeting, it was clear that the socialist proposal lacked a more profound and consistent theoretical analysis (KAUTSKY, 1986). Also, a better comprehension of the specificities of the process of penetration of capitalist relations in Europe was required, given the difference between the reality of the east, such as Russia, and the western countries, as in the case of the newly unified Germany. In the face of these two specific situations, two crucial works were published in 1899: The Agrarian Question by Karl Kautsky, and The Development of Capitalism in Russia by Vladimir Lenin.

For Kautsky (1986), the advance of capitalism in the countryside is an irreversible process, especially after the penetration of the logic of expanding production and private property through the use of modern techniques, inserted in an industrial logic. In this context, small peasant food production gives way to modern capitalist agriculture, based on private land ownership and wages. In his words: "agricultural prosperity and the persistence of peasant economic modes are two concepts that are excluded in the developed capitalist mode of production" (KAUTSKY, 1986, p. 63). He recognizes that new relationships could arise that would slow down the process of the disappearance of peasants and small properties, nevertheless, the demise of peasants and the territorial expansion of large capitalist property are inevitable phenomena due to the consolidation of capitalist logic. Kautsky recognized that this would not be a linear process, that is, it would meander due to the numerous factors involved. The coexistence between the large capitalist property and small peasant property could only be justified by complementarity, specifically, amid the penetration of capitalist relations of production in the agrarian space, small peasant properties would not compete with large capitalist properties, they would have a subordinate relationship.

Starting from the Russian reality of the second half of the nineteenth century, Lenin (1985) provides another important contribution to the theoretical debate on the agrarian issue. Faithful to classical Marxism, two fundamental questions served as a guiding thread for his analysis: understanding the process of capitalist development in Russia and the fate of peasants in that society. It is important to note that in studying these two issues, Lenin aimed to create a theoretical-ideological basis for the Russian Revolution, which occurred years later. For him, the advance of capitalism in the Russian context and the formation of markets, including land, would disintegrate small properties and, along with them, the peasants. This process would take place in two ways: on the one hand, some peasants 
would get rich by becoming part of a rural bourgeoisie, whereas medium and poor peasants would be evicted and converted into rural or urban workers. For Lenin, therefore, the more developed the capitalist mode of production, the more problematic the agrarian question will be, because, inevitably, there will be the rise of large properties that are close to the industrial logic and the disintegration of peasants.

Faithful to Marxist premises, both Kautsky and Lenin demonstrated the centrality of the debate on the agrarian question for the understanding of the social and economic transformations imposed by the dynamics of capitalism in Europe. Also, they placed the questions of private property and the peasants as protagonists of the debate.

Thus, while for Marxist socialists the question of private property of land is central in the debate of the agrarian issues, for liberals, land concentration, the precariousness of labor, and the end of the peasants and their relationships and traditions, are part of the normal process of development of the market economy. However, other interpretative lines were developed parallel to this debate, including the anarchist approach, of which Élisée Reclus was a supporter. What is the importance of the agrarian issue for an anarchist geographer? What is the role of the peasant class with the development of capitalism from an anarchist perspective?

\section{ÉLISÉE RECLUS' ANARCHIST DEBATE ON LAND}

Until 1850, young Reclus's attention was concentrated on understanding the foundations of anarchism and atheism. The anarchist perspective of freedom was the focus of his studies, and naturally, it was the topic addressed in his first political text, Développement de la Liberté dans le Monde (Development of Freedom in the World). However, at the start of his first exile, between 1851 and 1852, he worked as a farm manager in Ireland and realized that land was fundamental to guarantee citizen's freedom (FERRETTI, 2014 and 2016). The process of eviction of Irish peasants by large English landowners, which occurred amid a severe economic crisis in Ireland, awakened Reclus' awareness of how central the agrarian question was to understand the development of capitalism and peasant social poverty in Europe. He perceived that land was important both to consolidate the capitalist mode of production and as a potential element to support the outbreak of a revolution that would transform society by promoting social justice. (CHARDAK, 1997; PELLETIER, 2013; SARRAZIN, 2004)

Between 1853 and 1855, when he worked as a tutor for the children of a great slave farmer in the southern United States, Reclus grasped more deeply the role of private land ownership in the reproduction of capitalist relations and their impacts on agrarian space (BRUN, 2014). He was struck by the stark social reality surrounding him. On the one hand, farmers, supported by the Church and the State, concentrated huge portions of land where monoculture predominated, on the other, were enslaved workers without any guaranteed rights. The experience led him to abandon his job and travel across part of the American continent to New Granada (now Colombia) where he tried, unsuccessfully, to create a colonization project in which small properties, polyculture, and, above all, respect for the fundamental rights of citizens would predominate. (VINCENT, 2010; ZAAR, 2015)

Due to his personal experiences and the intellectual maturity ensuing from his study of anarchism, in the following decades, the agrarian issue became one of the most recurrent themes in his political writings. Extremely faithful to Pierre-Joseph Proudhon's principles of anarchism, in addition to positioning himself against private property and the structures of constituted power (State, Church, and Capital), Reclus created an analytic method that gave him a very particular interpretation of the agrarian question. For him, phenomena can only be understood by analyzing their dynamics, as part of the assumption that they are always in motion generated by the dialectical pair of evolution and revolution, which are understood as successive acts of the same process (RECLUS, 1880b and 1902).

Reclus' methodological reasoning is based on the principle that rather than being antagonistic or dichotomous concepts evolution and revolution are complementary. He refutes the common interpretation of the nineteenth century that classified evolution as synonymous with progress and revolution as equivalent to regression, disorder, and destruction of the status quo. For Reclus, evolution is all of a phenomenon's movement in time, which may be either progress or regression, and revolution involves changes in the foundational bases of the phenomenon. A dialectical movement occurs as the 
phenomenon evolves in a way that provokes the questioning of its first principles, giving rise to a revolution through the formation of new bases, which, in turn, inaugurate a new period of evolution. Reclus argues that this movement is the civilizing spiral that provides the elements for phenomena to be understood from the dynamics and relationships that give them meaning.

Based on this theoretical framework, Reclus ranks the agrarian issue as one of the most important phenomena of capitalist social dynamics. One of his first analyses was the case of Brazil, in the article entitled Le Brésil et la Colonisation (Brazil and Colonization), published in two parts in the year 1862, in which he makes incisive criticisms of Brazilian social organization. According to him, this society was first rooted in slave ownership and, in a second evolutionary moment, in the concentration of land. The latter "formed an aristocracy of planters" (RECLUS, 1862a, p. 931 - our translation), who did not appreciate the environment or the indigenous peoples, but who held the monopoly of the land and the production of goods for export. Reclus also criticized the treatment of immigrants who mostly worked on the land in colonies on large-scale farms. He believed that the promise of prosperity made to these immigrants could only be fulfilled when the land was free (RECLUS, 1862b).

In his work Évolution et Révolution (Evolution and Revolution), written for a lecture in 1880, when analyzing popular dissatisfaction, which could be the trigger for a revolution, Reclus argues that the land should only be occupied by workers, thus defending the main anarchist principle of the agrarian issue as posed by Bakunin (1873) in The land belongs to those who work on it. It also explains that the raised awareness of workers also occurs from the precariousness of their social conditions

\begin{abstract}
Now, the sound of the revolution echoes, shaking factories, parliaments, and thrones. Understandably, there was a sinister silence in the past when order reigned in Warsaw. [...] On the morrow of a massacre few men dare put themselves in the way of the bullets. When a word or a gesture are punished with imprisonment, men with the courage to expose themselves to the danger are few and far between. Those are rare who quietly accept the part of the victim in a cause, the triumph of which is as yet distant and even doubtful. Not everyone is as heroic as the Russian Nihilists, who compose manifestos in the very lair of their foes and paste them on a wall between two sentries. One should be very devoted to find fault with those who do not declare themselves Socialists, when their work, that is to say, the life of those dear to them, depends on the avowal. But if all the oppressed have not the temperament of heroes, they feel their sufferings none the less, and large numbers amongst them are taking their interests into serious consideration. In many a town where there is not one organized Socialist group, all the workers without exception are already more or less consciously Socialists; instinctively they applaud a comrade who speaks to them of a social state in which all the products of labor shall be in the hands of the laborer. This instinct contains the germ of the future Revolution; for from day to day it becomes more precise, transformed into a more distinct consciousness. What the worker vaguely felt yesterday, he knows today, and each new experience teaches him to know it better. And are not the peasants, who cannot raise enough to keep body and soul together from their morsel of ground, and the yet more numerous class who do not possess a clod of their own, are not all these beginning to comprehend that the soil ought to belong to the men who cultivate it? They have always instinctively felt this, now they know it, and are preparing to assert their claim in plain language.
\end{abstract}

(RECLUS, 1880b, p. 40-41 - emphasis added)

In the same year, he published the famous text Ouvrier, prends la machine! Prends la terre, paysan! (Worker, seize the machine! Seize the land, peasant!), written in the form of an article, but published as a pamphlet to be distributed to the workers of Paris, in which he defends the union between workers and peasants against private property (land and the means of production). Reclus argued that property owners deliberately fostered antagonism between urban workers and peasants to undermine any attempt to identify the two groups with the problems imposed by the development of capitalism, which would lead to the creation of workers' movements in favor of social transformation.

Our enemies, the defenders of private property, have always claimed that their best ally is the small landowner. Listening to them, Jacques Bonhomme watches over his piece of land day and night, waiting for some "terrible socialist" worker to grab him or hang him in the corner of his barn. According to them, the difference of interests between the peasant and the urban worker is so great that the antagonism of the two classes must remain forever and, of course, they count on this deadly hatred to maintain their power and 
money. (RECLUS, 1880b, p. 2 - our translation)

In the same text, Reclus criticizes most economists idealized view of peasant life as beautiful and peaceful and explains that land ownership is traditionally related to the power of some traditional families. In this sense, instead of belonging to those who work and produce food there, the land belongs to people who often have not even visited their properties, such as princes or bankers.

Leafy trees, rivers of pure water, an overflowing barn, bright-coated animals playing in the yard, a large farmer with his baby, surrounded by playing children, welcoming a smiling man who comes back from the fields, a fireplace, the hot food on the table as seen through the half-open door; all of this is graceful and sweet. But go and see the region of Silesia, where that idyll has turned into a horrible drama. There, there is no more fire, no meals, no clothes: men, women, and children are sick or dying on the bare earth and the hungry rats come to devour the corpses! The same is true of the private property regime. The land belongs to well-known personages: which is very bad for those who were not born princes or who were not lucky in life to become bankers! (RECLUS, 1880b, p. 3-4 - our translation)

In the 1886 text Pourquoi Sommes-nous Anarchistes (Why we are Anarchists), in which he presents the basic assumptions of the model of society defended by the Anarchists, Reclus defends collectivization and the rational use of land. He states that the main criterion of its division should be to guarantee people's well-being.

The land will become collective property, barriers will be removed and henceforth the ground belonging to all can be adapted to the enjoyment and well-being of all. The products required will be precisely those which the land can best provide, and production will respond exactly to needs, without ever wasting anything as in the disorderly work that is done today. In the same way, the distribution of all these riches amongst men will be removed from the private exploiter and will be done by the normal functioning of society at large. (RECLUS, 1886, p. 2)

Between 1891 and 1898, Reclus developed a deeper political analysis of the agrarian question in L'Évolution, la Révolution et l'Idéal Anarchique (Evolution, Revolution and the Anarchist Ideal), an extended and more reasoned version of the text Evolution and Revolution, that was only published in 1902. From the theoretical point of view, this work is the most important of the anarchist geographer's political texts. Besides expanding his explanation of his analytic method, detailing anarchist presuppositions, this text problematizes the issues related to private land ownership more profoundly.

For Reclus, the State, the Church, and Capital act to make the relationships between them increasingly more diffuse and nebulous in people's minds causing them to accept domination and the restriction of their freedoms. Based on this premise, he concludes that these three institutions are enemies of thought, equality, and freedom because they are the genesis that maintains private property. Once more, he proposes the alternative of the union between workers against the institutions of constituted power. In this context, the appropriation of land by peasants is as important for social transformation as the seizure of the factory by workers. He explains that “(...) it is through the appropriation of land and factories, already considered as the starting point of a new social era, that workers from all countries, gathered in congress, manifested themselves in perfect agreement" (RECLUS, 1902, p. 23 - our translation).

However, if the workers in several European cities were already starting to organize themselves into resistance movements based on anarchist premises, in the countryside the reality was extremely different. If the peasants were barely able to organize themselves into associations or cooperatives, how could they reject their fear of the workers and join them in a workers' union?

Thinking about this issue, in 1899 Reclus wrote À Mon Frère le Paysan (To My Brother, the Peasant) to provide training material for anarchist militants who would do the groundwork directly with the peasants. When discussing the conversion of peasants into workers (if there is no union and struggle), he states that land concentration is paramount for the penetration of industrial logic in the agrarian space modeled by what he called scientific exploration. At the same time, this scenario would 
generate a production of wealth never seen before, but also, destitution and precarious working relationships. He details this explanation, stating that:

If humanity's happiness consisted of creating a few millionaires who, to satisfy their whims and desires hoarded the produce amassed by all the subjugated workers, then this scientific exploitation of the earth would certainly be the dreamed-of ideal. [...] The expense incurred for a meagre wage yields an enormous amount of produce that is dispatched by the shipload and sold for ten times the cost of production.

\title{
(RECLUS, 1899, p. 14)
}

Some years later, Reclus described this situation in more detail in his last text discussing the agrarian issue: La Culture et la Propriété (Culture and Property), chapter VII of Tome VI of the work L'Homme et la Terre (The Earth and its Inhabitants). Written in 1904, but only published in 1908, it analyzes the historical evolution of private land ownership in various parts of the world. He believed that at the same time that private land ownership legitimizes inequality between people, it promotes the restriction of fundamental rights such as freedom of movement. He argues that "In considering the consequences of large property ownership, we must not forget the obstacles that it places in the way of free movement when the surrounding populations do not know how to bypass restrictions." (RECLUS, 1908 , p. 285). Therefore, he places the concentration of land ownership and the accumulation of wealth squarely within the process of reproduction of power structures.

\begin{abstract}
A major fact dominates modern civilization: the fact that a person's property can increase indefinitely and even, by almost universal consent, cover the entire world. The power of kings and emperors is limited, that of wealth is not. The dollar is the master of masters. It is for it, beyond any other reason, that men are distributed in various ways, here and there in cities, in the countryside, in workshops or factories, being pushed or pulled by work as if they were sediment from one river to another. (RECLUS, 1908, p. 256-257 - our translation)
\end{abstract}

Reclus' views on the agrarian question were clearly strongly influenced by the writings of the anarchist theorists Pierre-Joseph Proudhon (1841) and Mikhail Bakunin (1873) for whom the struggle against private property and the foundation of a new society, without State, Church, or Capital, would be at the heart of a solution to the latent problem at the end of the nineteenth century. However, his experience of various realities throughout his life and the geographical focus of his analytical vision focused meant he had additional elements in his study of the peasant question than these two influential authors.

\section{ÉLISÉE RECLUS’ VIEWS ON THE PEASANT ISSUE}

Reclus's anarchist analysis of peasants is based on his understanding of the implications of the expansion of capitalist relationships into the countryside. Whilst Marxism discussed the peasantry as an archaic mode of production and a unit of production at risk of disappearance, anarchists viewed them as members of the exploited working class whose freedom was curtailed by private land ownership. Another important element that differentiates the two positions is the role of peasants in the revolution. In general, Marxists were strongly influenced Karl Marx's work The Eighteenth Brumaire by Louis Bonaparte, written in 1852, in which, when analyzing the French socio-political context between 1848 and 1851, which culminated in Napoleon III's coup, he states that:

The small-holding peasants form an enormous mass whose members live in similar conditions but without entering into manifold relations with each other. Their mode of production isolates them from one another instead of bringing them into mutual intercourse. The isolation is furthered by France's poor means of communication and the poverty of the peasants. Their field of production, the smallholding, permits no division of labor in its cultivation, no application of science, and therefore no multifariousness of development, no diversity of talent, no wealth of social relationships. Each peasant family is almost self-sufficient, directly produces most of its consumer needs, and thus acquires its means of life more through an exchange with nature than in intercourse with society. A smallholding, the peasant and his family; beside it 
another small holding, another peasant and another family. A few score of these constitute a village, and a few score villages constitute a department. Thus, the great mass of the French nation is formed by the simple addition of homologous magnitudes, much as potatoes in a sack form a sack of potatoes. Insofar as millions of families live under conditions of existence that separate their mode of life, their interests, and their culture from those of the other classes, and put them in hostile opposition to the latter, they form a class. Insofar as there is merely a local interconnection among these small-holding peasants, and the identity of their interests forms no community, no national bond, and no political organization among them, they do not constitute a class. They are therefore incapable of asserting their class interest in their own name, whether through a parliament or a convention. They cannot represent themselves; they must be represented. Their representative must at the same time appear as their master, as an authority over them, an unlimited governmental power which protects them from the other classes and sends them rain and sunshine from above. The political influence of the small-holding peasants, therefore, finds its final expression in the executive power which subordinates society to itself. (MARX, 1982, 144-145)

This interpretation assesses that the peasants are unable to organize themselves politically or socially. This differs substantially from the anarchist thesis, as well as their views on the direction of the analytical discourse. While for Marxists peasants would be the subjects who supported the revolution, for anarchists they would be the subjects that built it. Furthermore, while the Marxists talked about the peasants, the Anarchists prioritized talking to the peasants, inviting them to unite and act. Élisée Reclus was a central figure in this task, given that his interpretation of the peasant issue was outlined together with the anarchist militancy, to whom he dedicated most of his political texts. He aimed to enlighten and engage the militants because they would have direct and daily contact with the subjects of the revolution (workers and peasants) and develop training and awareness-raising, that is, the basis of the revolution that would found the pillars of an anarchist society.

Based on the anarchist assumption of awareness-raising awareness, which was designed to achieve the intellectual emancipation of individuals and promote social transformation, Reclus sought to use more accessible language in his texts intended to explain important themes to the activists who would have contact with European peasants in last two decades of the nineteenth century. He highlights the importance of understanding how land was being appropriated in the former European colonies, which was viewed by many European economists, agronomists, businessmen, and politicians as an example worthy to be followed.

May the peasants of Europe stay informed! Do not doubt if, soon, the capitalists do here what they considered appropriate to do on the other side of the Atlantic, because precisely those who give us information about American farms are commissioners charged by the English government to import good farming methods into Europe. (RECLUS, 1880b, p. 4-5 - our translation)

Reclus sought to highlight the fundamental role of the land in preserving the freedom of the European peasant mass. For him, maintaining communal lands and ties of solidarity is at the heart of peasant existence, as the process of the fragilization of the peasants' life and work begins with the transformation of communal lands into small individual properties, which undermines the social balance required for the social relationships between these subjects (RECLUS, 1880a, 1880b and 1908). Given this reality, the political texts on the peasant issue also aimed to highlight the importance of the struggle and resistance against the expansion of capital in the countryside, which would inevitably generate even more land concentration, expropriation, and precarious working relationships.

The peasant who owns a piece of land can enjoy his existence, like the artisan and the petty-bourgeois, as the moment will come when all competition with the great exploiter of the land, served by capital and by machine, will become completely impossible and on that day, all that will remain will be to become a beggar. Unless, together with the urban worker, his companion at work and in misery, he finally regains common property! (RECLUS, 1880b, p. 7-8 - our translation)

It is quite clear that the potential of the peasants' political action should not be not underestimated but instead stimulated by the militants. This was the only way that peasant existence would be possible. 
In the text To My Brother, the Peasant, for example, Reclus strives to clarify the importance of raising awareness and mobilizing workers for social transformation along the anarchist lines. According to him, in a revolution, the land of concentrators, speculators, and those who, despite not having much land, exploit the work of others will not be respected. This land will be destined for peasant families who will work in food production to supply society. Also, the size of the peasant area should be that which the family can cultivate. However, this will only happen if the peasants are united, because "Completely alone, the small farmer [...] is too weak to struggle against a miserly nature and an evil oppressor at the same time. If he survives, it is through a feat of willpower. He must adjust to all the whims of the weather and submit a thousand times to voluntary torment". (RECLUS, 1899, p. 3-4)

Reclus recognizes that the peasants' relationship with the land is vastly different from that of the great landowner. For the peasant, it goes beyond the economic sphere because the land is, simultaneously, the locus of home, work, and solidarity with their peers. However, none of these elements is sufficient to free them from the destiny that the expansion of capitalist logic in agriculture holds for them. Loving the land is not enough! Only unity and political action are capable of changing the destiny promoted by capital. "If all the peasants in the same region had understood how much union can increase their strength against oppression, they certainly would never have left the communities of primitive times to perish (...)"(RECLUS, 1899, p. 6 - our translation).

For Reclus, the peasant class is at the heart of the struggle against capitalism because its organization is supported by a completely distinct logic, in a way of life that is genuinely associative, solidary, supported by the cooperative practices of mutual aid, collective effort, exchange of food, inheritance relations, marriage, work, and coexistence. Therefore, the fabric of peasant life is anchored in the association between equals in the management of land, work, and life, a form of organization defended by anarchist thought.

\footnotetext{
Their collective property is not divided into countless enclosures by hedges, walls, and ditches. They do not have to quarrel over the ownership of an ear of corn growing to the right or the left of the furrow. There are no bailiffs, attorneys, or notaries to regulate business between comrades. After the harvest and before the time comes to begin their work again, they gather to discuss their common interests. The young man who has just married, and the family that has a new child or taken in a guest, explain their new situation and take a larger portion of the common resources to satisfy their increased needs. Boundaries are decreased or increased according to the availability of land and the number of members. Each cares for his field, happy to be at peace with his brothers, who work their share of the land, which has been apportioned to meet the needs of all. During emergencies, the comrades help each other out. If a fire devours one of the cottages, all participate in rebuilding it. If a gully erodes part of a field, another portion is granted to the holder of the damaged land. One person grazes the community's herds, and in the evening, the sheep and cows follow the road back to their stables without being driven. The commune is at once the property of each and of all. (RECLUS, 1899, p. 6-7)
}

However, union among peasants must also be composed of political action to prevent the isolation or disappearance of this social class. Furthermore, peasants must ally themselves with urban workers against the precariousness of labor relations and living conditions, given that the landowners and industrial owners have the Law, the Church, and politics in their favor. Thus, it is not worthwhile for peasants only to unite in a commune when they are about to lose the land demanded by a lord.

Thus all you small landowners, whether isolated or joined in communes, are indeed weak against those who try to enslave you, who are after your small plot of land, and the authorities who try to take all the income from it. If you do not know how to join together, and not just from individual to individual or from commune to commune, but from country to country in a great international of workers, you will soon share the fate of millions upon millions of men who are already stripped of all rights to sow and reap and who live as wage slaves. They find work when the bosses are interested in giving it to them and are always obliged to beg in a thousand ways, sometimes asking humbly to be hired, sometimes even holding out their hands to plead for a meagre pittance. They have been deprived of land, and you might be among them tomorrow. (RECLUS, 1899, p. 5)

His great knowledge of the North American agrarian reality provided Reclus with important elements to sustain his discourse directed to the peasants, based on the fight against the great capitalist 
property, sustained by monocultures and the wage system. Also, his studies on revolution and human dignity enabled him to propose alternatives in the fight against the process of expansion of capitalism, both in the countryside and in the city. For him, before the barricades are erected, the revolution must happen in the workers' minds and hearts (RECLUS, 1902). From this idea, in his political texts in which he addressed the issue, Reclus created a kind of rallying cry, to evoke the workers into the struggle:

Negro of the factory, Convict of the mine, Destitute of the fields, Arise, mighty people: Worker, seize the machine! Seize the land, peasant! (RECLUS, 1880a, p. 8; 1880b, p. 39; 1902, p. 261-262 - our translation)

The awareness-raising for action to transform the existing model of society has always been present in Reclus' analysis of the peasantry. Nevertheless, at the beginning of the twentieth century, when writing his last great work L'Homme et la Terre (The Earth and its Inhabitants) he puts into words his observations over at least two decades: the disappearance of the peasantry - a thesis defended by Marx, Lenin, and Kautsky.

(...) The peasant we traditionally know is disappearing. As the form of land ownership changes, it will change in the same proportion. Even the small landowner who tries to follow in his father's footsteps and desperately clings to the old farming routine cannot ignore his neighbor's methods, nor can he close his ears to the stories he hears at the fairs. He realizes that the circle of interests around him is closing, even if he does not clearly understand that, for example, Russian wheat and American corn compete with his products and decrease their sale value. Also, he is increasingly affected by the specialization of work, which brings him closer to the situation of urban workers due to their involvement with large industry. As the exploration of the land has become more scientific, he can see that the differences from the workers of the city are diminishing. From proletarian to proletarian, the classes are confused, as has already happened between landlords and industry owners. (RECLUS, 1908, p. 294 - our translation)

Even understanding that the development of capitalism in the countryside will lead to the disappearance of the peasants, transforming them into proletariats, Reclus considers that the peasant class and common lands will not completely disappear because, even in smaller numbers, they will be territories of resistance to the capitalist logic and reproduction of their way of life.

Taking as an example the great expansion of private land ownership in Europe between the sixteenth and nineteenth centuries, he states that:

In fact, there is not a single country in Europe where the traditions of the old community properties have completely disappeared. In certain regions of the Ardennes and on the steep slopes of Switzerland, where peasants were not crushed like the German villagers after the Reformation wars, common properties are still large enough to constitute a considerable part of the territory. (RECLUS, 1908, p. 268 - our translation)

Reclus also considers that the customary elements related to peasant morality and created from the meeting of immediate needs (housing, food, work), unite them, developing bonds of solidarity, which form the peasant resistance. However, although they can slow the process of expanding private land ownership and the logic of industrial production in the agrarian space, the peasant way of life is constantly under threat. (RECLUS, 1908)

\section{CONCLUSION}

The social and territorial impacts of the expansion of private land ownership in the nineteenth century were the thread for various interpretations of the agrarian issue in capitalism. However, for a long time, this debate was centered on the theoretical-methodological and political opposition between liberals and socialists, making other analyzes, such as the anarchist one, relatively neglected by later studies.

After the split between socialists and anarchists at the Hague Congress in 1872, anarchist thinking regarding the penetration of capitalist relationships and industrial logic in the countryside developed 
more faithfully to its premises. Reclus' theoretical-methodological approach to the study of the agrarian question, and more specifically to the understanding of the peasant question in capitalism, is an excellent example of this fidelity. Also, it is important to highlight the pioneering spirit of the anarchists in the creation of a collectivist project that proposed alternatives to the conflict established in the countryside, which was deliberated, debated, and proposed almost two decades before the socialists did so, in which Reclus actively participated.

Reclus contributed to the elucidation of the main divergences between socialists and anarchists, including the role of the State in social transformation, the potential for peasant organization, the change in the peasant's way of life due to the decline of common land, and the changes to the peasants' relations if a small number of them were converted into petty-bourgeois.

If, for the socialists, the State should exist to promote the transformation of society towards a more just organization, together with the people and respecting their interests, for anarchists the State corrupts and is corrupted by those who hold power. Thus, as Reclus defended in all his political works, there is no need to consider the existence of the State.

Concerning the potential of peasant organization pointed out by Reclus, an analysis of the fundamentals of the anarchist's collectivist program, the theoretical basis for the development of his interpretation of the agrarian issue, plainly reveals the divergences with the socialists. For anarchists, peasants are collective subjects (in their way of life, work, etc.), therefore, they considered that Marx underestimated their capacity in the organization and action in society. So, anarchists deny the perception of peasants as instruments of the revolution by defending the peasantry as builders and protagonists of transformation, together with the workers.

Based on the writings of Proudhon and Bakunin on private land ownership, Reclus argues that the precariousness of peasant life and work begins with the extinction of common land, stressing that it is no use for the peasant to be a small landowner because his social and material existence is outlined by the collectivity. Thus, he shares these two leading anarchist thinkers' ideas, pointing out that smallholders have an antagonistic relationship with their exploiters, that is, Reclus does not share the socialist thesis that some peasants would achieve prosperity and become part of the bourgeoisie. For him, what determines the peasants' existence and social reproduction is work and not property. For this reason, anarchists defend a union between peasants and workers to construct a revolution founded on the pillars of society along anarchist lines. However, the union between workers against State, Church and Capital, as Reclus preached in all his political texts, must be based on a collectively built popular ideal, which requires the active role of the militancy together with the subjects of the revolution so that the peasants' wishes are also contemplated, making these subjects view themselves as representatives and represented in the struggle to reach this ideal.

\section{REFERENCES}

BAKUNIN, Michel. Étatisme et Anarchie. Paris: Stock Éditeur, 1873.

BRUN, Christophe. Élisée Reclus: les grands textes. Paris: Flammarion, 2014.

CHARDAK, Henriette. Élisée Reclus: l'homme qui aimait la Terre. Paris: Éditions Stock, 1997.

ECCLESHALL, Robert. Ideologías Políticas. 3ª edição. Madrid: Tecnos, 2011.

FERRETTI, Federico. Élisée Reclus: pour une géographie nouvelle. Paris: Editions du CTHS, 2014.

FERRETTI, Federico. Evolução e Revolução: os geógrafos anarquistas Élisée Reclus e Pëtr Kropotkin e sua relação com a ciência moderna, séculos XIX e XX. História, Ciência, Saúde - Manguinhos, Rio de Janeiro, v. 25, n. 2, jun. 2018. Disponível em: https://www.scielo.br/scielo.php?script=sci_arttext\&pid=S0104-59702018000200553\&lng=pt\&tlng=pt. Acesso em: 30 mar. 2020.

FERRETTI, Federico. Breve Cronologia da Vida de Élisée Reclus (1830-1905). Terra Brasilis [Online], 7, 2016. Disponível em: http://journals.openedition.org/terrabrasilis/1764. Acesso em 20 jan. 2020. 
HEGEL, Georg Wilhelm Friedrich. Princípios da Filosofia do Direito. São Paulo: Martins Fontes, 2003.

HOBSBWAM, E. História do marxismo. Rio de Janeiro: Paz e Terra, 1983.

KAUTSKY, Karl. A Questão Agrária. São Paulo: Nova Cultural, 1986.

LÊNIN, Vladimir. O Desenvolvimento do Capitalismo na Rússia: o processo de formação do mercado interno para a grande indústria. São Paulo: Nova Cultural, 1985.

MARQUES NETO, Agostinho Ramalho. Neoliberalismo e Gozo. In: VESCOVI, R. C. (Org.). A Lei em Tempos Sombrios. Rio de Janeiro: Companhia de Freud, 2009, p. 51-68.

MARX, Karl. O 18 Brumário de Louis Bonaparte. Lisboa: Avante!, 1982. Disponível em: https://www.marxists.org/portugues/marx/1852/brumario/index.htm. Acesso em: 04 abr. 2020.

MARX, Karl. Debates on the Law on Thefts of Wood. In: MECW. London: International Publishers, 1975.

NABARRO, Sergio Aparecido. Modo de Vida e Campesinato no Capitalismo: contribuições, limites e a construção de um entendimento do campesinato como modo de vida. Tese (Doutorado em Geografia). Universidade de São Paulo, São Paulo, 2014.

PELLETIER, Philippe. Géographie e Anarchie: Élisée Reclus, Pierre Kropotkine, Léon Metchnikoff et d'autres. Paris: Éditions du Monde Libertaire, 2013.

PROUDHON, Pierre-Joseph. Qu'est-ce que la propriété? Recherche sur le principe du Droit et du Gouvernment. Paris : Librairie Prévot, 1841.

RECLUS, Élisée. Le Brésil et la Colonisation: le bassin des amazones et les indiens. Revue des Deux Mondes, 15 jun. 1862. Paris, 1862a.

RECLUS, Élisée. Le Brésil et la Colonisation: les provinces du littoral, les noirs et les colonies allemandes. Revue des Deux Mondes, 15 jul. 1862. Paris, 1862b.

RECLUS, Élisée. Évolution et Révolution. Le Révolté, n² 27, 21 février, p. 1-3. Genebra, 1880a.

RECLUS, Élisée. Ouvrier, prends la machine! Prends la terre, paysan! Genebra: Imprimerie Jurassienne, $1880 \mathrm{~b}$.

RECLUS, Élisée. Pourquoi sommes-nous anarchistes? La Tribune des Peuples - Maio/1886. Paris, 1886.

RECLUS, Élisée. À mon frère, le paysan. Genève: Imp. Des Eaux-Vives, 1899.

RECLUS, Élisée. L'Évolution, la Révolution et l'Idéal Anarchique. Paris: Stock Éditeur, 1902.

RECLUS, Élisée. L’Homme et la Terre - tome I - Les Primitifs / Histoire Ancienne. Paris: Librairie Universelle, 1905.

RECLUS, Élisée. L'Homme et la Terre - tome VI - Histoire Contemporaine. Paris: Librairie Universelle, 1908.

RECLUS, Élisée. Développement de la Liberté dans le Monde. Le Libertaire, $\mathrm{n}^{\circ} 22$ ( 28 de agosto), $\mathrm{n}^{\circ} 23$ (04 de setembro), $\mathrm{n}^{\circ} 25$ (18 de setembro), $\mathrm{n}^{\circ} 26$ ( 25 de setembro) e $\mathrm{n}^{\circ} 27$ (02 de outubro), Paris, 1925.

ROUSSEAU, Jean-Jacques. Du Contrat Social: ou principes du droit politique. Paris: Éditions Garnier Frères, 1962.

SARRAZIN, Hélène. Élisée Reclus: ou la passion du monde. Paris: Éditions du Sextant, 2004.

VIEIRA, Júlia Lemos. O Problema da Propriedade Privada para o Jovem Marx. Revista Trans/Form/Ação, Marília, v. 42, n. 2, p. 123-150, Abr./Jun., 2019.

VINCENT, Jean-Didier. Élisée Reclus: géographe, anarchiste, écologiste. Éditions Robert Laffont: Paris, 2010. 
ZAAR, Mirim Hermi. A Questão Agrária na Obra Geográfica de Élisée Reclus. Ateliê Geográfico Goiânia-GO, v. $9, \quad$ n. $3, \quad$ p. 43-62, dez/2015. Disponível em: https://www.revistas.ufg.br/atelie/article/view/37627. Acesso em 20 jan. 2020. 